\title{
'What's this about a new mission?': Assimilation, resistance and the Morwell transit village
}

Beth Marsden

\begin{abstract}
This article demonstrates the destructive intent of assimilation policies through attempts at forced movement into artificially created 'communities', such as the Morwell transit village in Victoria, Australia, in the 1960s. It argues that the resistance by Indigenous people to forced assimilation was strong, and that the challenges that they, and their supporters, made to assimilation and housing policies, were effective in contesting attempts to disconnect Indigenous people from their land.
\end{abstract}

In June 1965, the Victorian Aborigines Welfare Board (the Board) was offered a 15-year lease on 4 acres of swampy land on the outskirts of Morwell, in Victoria's Latrobe Valley. The site was wedged between the railway line and the busy Princes Highway, prone to flooding, and zoned for industrial use. ${ }^{1}$ The Board planned to use the site to develop a 'transit village', in order to 'bring to Morwell all the aborigines [sic] now living at Lake Tyers'. ${ }^{2}$ This announcement drew condemnation from Aboriginal leader Doug Nicholls. In a statement on behalf of the Aborigines Advancement League, Nicholls attacked the 'setting up of a new fringe settlement' in Morwell, suggesting the plan was a 'continuation of the Government's policy of arbitrarily acquiring land and placing Aboriginal families thereon in areas which are alien to them'. Nicholls challenged the government's approach to assimilation,

1 National Archives of Australia (hereafter NAA), B357, 77; Fletcher, Chesters and Drysdale, 'Past, Present, Future', 22.

2 'Deadlock on Plan to Settle Aborigines', Morwell Advertiser, 17 May 1965, 1. 
declaring that no government or person had the right to say that Aboriginal people 'must assimilate and live in a particular area'. ${ }^{3}$ Nicholls's protests - and those of other Aboriginal leaders and activist groups - against the Morwell transit village were part of the broader and longer campaign by Aboriginal people to stop the closure of the last remaining Aboriginal reserve in Victoria, at Lake Tyers. By the end of 1965 the Morwell transit village scheme had been abandoned by the Board, and the threat posed to Lake Tyers was defeated in part due to their protests.

This article provides a detailed examination of the short-lived Morwell transit village scheme. This research contributes to the examination of the longer history of attempts to dispossess and control Aboriginal people in Victoria through missions, reserves and housing programs. Penny Edmonds has examined the colonial construction of urban spaces as 'ordered and civilised' where Aboriginal people were subjected to a range of 'civilising' influences. ${ }^{4}$ The reordering of space under the hand of missionaries at Ebenezer and Ramahyuck as examined by Jane Lydon and Bain Attwood respectively shows the importance invested in controlling and managing spaces with the aim of affecting the behaviour of Aboriginal people. ${ }^{5}$ In particular, this article examines the intended assimilatory effects of transitional housing settlements informed by the motivation of government to disrupt Aboriginal communities and connection to land. Historians Jo Woolmington and Heather Goodall have interrogated the intended assimilatory effect of Aboriginal housing programs in New South Wales, and Corrine Manning has examined the spatial politics at work in transitional housing settlements in Victoria in the postwar era. ${ }^{6}$ These scholars have shown how the intended educative and transformative influence of housing was key to assimilation policies in the mid-twentieth century. As the last attempt of the Victorian Government to develop an overtly assimilationist transitional housing program, the Morwell transit village scheme provides an insight into how government aimed to use highly controlled housing settlements to further their assimilationist aims. The ongoing campaign to save Lake Tyers, which has been detailed elsewhere, was part of the broader movement of Aboriginal activism: within this story, the fight against the Morwell transit village demonstrates the complexity of grassroots resistance and political activism against government policies of assimilation in Victoria. ${ }^{7}$

\footnotetext{
3 Doug Nicholls, 'Statement on Aboriginal Affairs by Mr Rylah', 1 April 1965, Council for Aboriginal Rights (hereafter CAR) Papers, State Library Victoria (hereafter SLV), MS12913, Box 3/7, emphasis in original.

4 Edmonds, 'Intimate, Urbanising Frontier', 129-54.

5 Lydon, Fantastic Dreaming, 100-18; Attwood, Making of the Aborigines.

6 Woolmington, 'The "Assimilation” Years', 25-37; Goodall, 'Assimilation Beings in the Home', 75-101; Manning,

'A Helping White Hand', 193-208; Manning, 'Victoria's Transitional Aboriginal Housing Policy', 221-36.

7 See Attwood, Rights for Aborigines; Broome, Aboriginal Victorians, 194-99, 217-57; Taffe, 'Fighting for Lake Tyers'. The publicity surrounding protests both internationally and within Australia resulted in issues of race becoming more prominent in the public consciousness. Groups such as the Federal Council for the Advancement of Aborigines ensured the dissemination of ideas and strategies for Aboriginal activists and their supporters. The Wave Hill walk-off, the Yirrkala petition and the Freedom Rides were well-publicised symbols of Aboriginal resistance, see Chesterman and Galligan, Citizens without Rights.
} 
Aboriginal resistance to the transit village was key to the ongoing campaign to save Lake Tyers and was part of a broader movement of Aboriginal activism during the 1960s. ${ }^{8}$ The role of the Council for Aboriginal Rights in fighting to save the reserve has been detailed by historians Sue Taffe and Richard Broome, who show that the growing relationships between Aboriginal people and non-Aboriginal activists were effective in challenging the Board's policies and practices. Broome's examination of the fierce activism of the Aborigines Advancement League (the League) illustrates the importance of the League's involvement in the campaign for Lake Tyers. ${ }^{9}$ These histories also demonstrate how Aboriginal leaders and individuals engaged with and negotiated assimilationist practices as they were enacted politically, and on the ground. This article contributes another perspective to this pivotal time of resistance to assimilation practices enacted without Aboriginal consultation.

The development of assimilation policy in Australia has been examined by many historians. Anna Haebich and Tim Rowse show how assimilation became the dominant trend in Aboriginal policy, yet was interpreted and implemented in multiple different ways. ${ }^{10}$ Broome's meticulous history of Aboriginal experiences and resistance to Victorian assimilation policies illustrates the many different ways that assimilation was enacted by the Board, the Board's staff, and non-Aboriginal groups and individuals. ${ }^{11}$ This article draws on the work of these scholars to examine how assimilationist practices were contested and negotiated in mid-1960s Victoria, and Rowse argues that there is a need to acknowledge that there was and is no fixed meaning or definition of the term. Indeed, while this case study shows how some members of the Aborigines Welfare Board understood and enforced a version of assimilation that was based primarily on housing and the closure of Lake Tyers, it also illustrates the layers of assimilative pressures enacted by white communities, groups and individuals in the name of assimilation.

The story of the Morwell transit village has, up to this point, received only passing attention from historians in discussions of Lake Tyers and the campaign to save the reserve from closure. ${ }^{12}$ This article argues that the failure of the transit village demonstrates how multilayered resistance-both political and grassroots-could operate against government policies of assimilation and dispossession in Victoria. I argue that this resistance, in combination with the publicised campaigning of Doug Nicholls, Laurie Moffatt and the Council for Aboriginal Rights and the Aborigines Advancement League, contributed to the rejection of the Morwell transit village and to the retention of Lake Tyers reserve. The story of this scheme is worthy

\footnotetext{
Taffe, 'Fighting for Lake Tyers', 157-71; Broome, Aboriginal Victorians, 194-99, 217-57.

Broome, Fighting Hard, 99-116.

10 Haebich, Broken Circles; Rowse, 'Contesting Assimilation', 1-24.

11 Broome, Aboriginal Victorians, 183-337.

12 Broome, Aboriginal Victorians, 106, 109-10; Broome, Fighting Hard, 109-10.
} 
of further attention as an example of Aboriginal resistance to the forced closure of Victoria's reserves, and to the destructive aims of the assimilation policy that targeted Aboriginal family and kinship networks that were fostered at Lake Tyers. ${ }^{13}$

This article outlines the context for the development of the Morwell transit village scheme. This includes an overview of the Aborigines Welfare Board's plans for the village, including the involvement of key figures from outside the Board in the spatial and pedagogical aspects of the design. In the second part of this paper, I turn my attention to the political and grassroots activism of Aboriginal leaders Doug Nicholls and Laurie Moffatt to challenge the Morwell transit village scheme.

\section{The Victorian Aborigines Welfare Board: Housing, Lake Tyers and the idea of a transit village}

In the postwar period, Aboriginal communities in Victoria based in camps on riverbanks, in the bush and on the outskirts of towns that had previously ignored them began to attract official attention. The Liberal Government commissioned an inquiry and the subsequent report, based on a partial survey of Aboriginal people around the state, undertaken by Charles McLean, a retired Chief Stipendiary, resulted in the Victorian Government formally adopting the policy of assimilation in a new piece of legislation, the Aborigines Act $1957 .{ }^{14}$ The largely inactive Board for the Protection of Aborigines was abolished, and the new Aborigines Welfare Board was charged with implementing the assimilationist policy encoded in the Act. The main thrust of the Board's activities was directed towards clearing away the camps, moving Aboriginal people into standard housing, and closing Lake Tyers. These policy aims were directed towards Aboriginal people living together in groups, both on and off government-managed spaces, who had a strong sense of community and Aboriginal identity. ${ }^{15}$ The proposal for the Morwell transit village scheme in 1965 was one of several attempts by the Board to achieve their aim of assimilation in Victoria.

The Board acted swiftly to break up camps, a process that had been started by local councils in 1957. They established 2 isolated transitional housing settlements, the first at Rumbalara in 1958, on the outskirts of Mooroopna, followed later by Manatunga at Robinvale in 1960. As Corrine Manning has shown, these settlements were designed to facilitate the 'transition' of residents from camps to standard

\footnotetext{
13 Broome, Aboriginal Victorians, 325; Taffe, 'Fighting for Lake Tyers', 170.

14 McLean, 'Report', Victorian Parliamentary Papers, 1956-58, Vol. 2, Paper no. 18, 6.

15 Atkinson, quoted in Jackomos and Fowell, Living Aboriginal History, 182; Lovett, quoted in Jackomos and Fowell, Living Aboriginal History, 186.
} 
houses, but they were poorly designed, the construction was substandard and the surveillance of white managers, who collected rent and tried to prevent visitors, offended many of the residents. ${ }^{16}$ The Board recognised that a different approach was required to break up Lake Tyers. The living conditions on the reserve in the late 1950s were dire, following decades of incompetent management and inadequate maintenance. The state government resisted making any improvements or repairs to the infrastructure on the reserve from 1958 on the basis that the reserve would soon be closed in accordance with the legislation. ${ }^{17}$ Most of the Board's expenditure went on houses in country towns around the state that were offered first to families living on Lake Tyers, despite the housing insecurity experienced by many other Aboriginal families, particularly in Gippsland. ${ }^{18}$

The new Board met once a month. By 1964, these meetings were dominated by 3 members: Harry Davey, Don Howe and Arthur Holden. Davey, who represented the Minister for Housing, had recently retired from a long career with the Housing Commission. Arthur Holden ran an accountancy firm in Morwell, and Don Howe owned a commercial orchard in the Goulburn Valley that employed Aboriginal workers. ${ }^{19}$ As scholar Mark Harris has argued, these 3 members formed a powerful 'coterie', controlling most of the Board's policy and practices by 'rigidly excluding any opinion at variance with their own'. ${ }^{20}$ They formed a housing subcommittee through which they controlled the processes of the Board and directed resources towards the acquisition of housing. ${ }^{21}$

Davey, in particular, was very active in his role. He travelled throughout the state buying up blocks of land and houses in country towns, liaising with local real estate agents and building contractors. ${ }^{22}$ Although the Board claimed that families from Lake Tyers who decided to take up the offer of a new house would be given a choice as to where they could live, Davey controlled the allocation of housing. The request made by a family from Lake Tyers for a house in Warragul was dismissed by Davey, who commented that they would 'be better located in some isolated small Gippsland town under supervision'. ${ }^{23}$ Under his direction, the Board's housing subcommittee operated on the expectation that isolation from larger group structures, as well as the experience of living in 'standard housing' in white communities, would encourage Indigenous people to abandon their culture, lifestyle and values in favour of the white equivalent.

16 Manning, 'A Helping White Hand', 193-208; Manning, 'Victoria's Transitional Aboriginal Housing Policy', 221-36.

17 NAA, B314, 10.

18 NAA, B336, 1; see also AWB Housing (Member) files B336, 25-27, for example.

19 Broome, Fighting Hard, 107-8; NAA, B336, 23.

20 Harris, 'A "New Deal", 116.

21 NAA, B314, 11.

22 NAA, B336, 1; see also B336, 25-27, for example.

23 NAA, B356, 44. 
The Board's housing program provided a visible representation of assimilation at work to white communities around the state. Local branches of community groups such as the Apex Club and the Country Women's Association (CWA) were involved in the provision of housing and material resources for Aboriginal families in Gippsland. ${ }^{24}$ The Board, under-resourced and understaffed, encouraged the sense of civic responsibility held by these groups, and directed their resources and enthusiasm towards housing as a community project. ${ }^{25}$ In Morwell, the Apex Club directed attention to the 'sponsorship' of families from Lake Tyers. They were heavily involved in the provision of housing for 2 families who moved to Morwell in 1959. 'Sponsorship' came with supervision and expectations: the club informed one man from Lake Tyers that a house was available on the condition that he 'did not bring any relations' with him, adding that 'we sincerely hope this venture will be a complete success. ${ }^{26}$ Arthur Holden had been involved in the Apex Club in Morwell before he became a member of the Board in 1961, and had been the director of the Aboriginal sponsorship scheme launched by Apex in $1956 .{ }^{27}$ Following his appointment to the Board, he continued to work with local residents to find housing for families from Lake Tyers as part of Morwell's 'Aboriginal Welfare Board Local Committee'. ${ }^{28}$ This group made inquiries into and inspections of property and housing in the area for the Board to purchase, recommended which houses the Board should buy and to which families they should be allocated. ${ }^{29}$ The connection between the Board and the local committee in Morwell through Holden is illustrative of the blurring of official policy and the interpretation of assimilation by individuals who had no knowledge of the values, aspirations and needs of Aboriginal people.

For families who moved into country towns away from Lake Tyers, the gaze of community groups and white neighbours was underscored by regular inspections by the Board's property inspector. ${ }^{30}$ Residents were not permitted to have guests, or to make modifications to their houses, such as the hanging of curtains. ${ }^{31}$ Many residents defied the Board's efforts to control their use of housing and the traces of this resistance is evident in the reports of property officers: those who challenged the inspections were described as 'antagonistic' and one family who shared their house with visitors was described as 'openly defying the Board'. Sometimes residents

\footnotetext{
24 NAA, B336, 3; the CWA funded a house in Drouin for an Aboriginal family, Landon, Jackson's Track Revisited, 412.

25 Community involvement in the project of assimilation has received some attention from scholars, who have examined how the varied understandings of assimilation included expectations and conditions that did not necessarily align with what Aboriginal people wanted, see Woolmington, 'The "Assimilation" Years', 25-37; Jones, 'Aboriginal Education', 122-39; Haebich, Broken Circles, 492-94.

26 NAA, B336, 3.

27 Manning, 'The McLean Report', 170.

28 B336, 1; see also B336, 25-27, for example.

29 NAA, B336, 31; Victoria, Aborigines Welfare Board, Annual Report, 1962.

30 NAA, B358, 4.

31 NAA, B358, 4.
} 
flatly refused to pay rent or repeatedly stalled on their payments. ${ }^{32}$ Other families forfeited their houses by leaving without notice. This frustrated and baffled the Board's staff, as evidenced in comments such as, 'for reasons which have not been completely assessed, the families left the accommodation arranged'..$^{33}$ The sharing of houses, in particular, drew the ire of the welfare staff and of the Board. Sharing subverted the aims of the Board's entire approach to housing that was based on separating families from one another in houses designed for nuclear families.

The Board's Superintendent, Philip Felton, challenged adverse representations of Aboriginal use of and movement between housing. Felton was a trained social worker and his views on policy frequently differed from those held by Davey, Holden, Howe and the government. ${ }^{34} \mathrm{He}$ recognised that the presence of some visitors in Board housing could be problematic for Aboriginal families, but he resisted the generalisation that all visitors and the pattern of visiting needed to be stopped, stating that ' $\mathrm{i}] \mathrm{t}$ is no solution to urge that "blow-ins" be kept out of houses ... This is part of an accepted way of life; it is not a question of irresponsibility or indigence' ${ }^{35}$ Felton's opinions had little impact on the Board's approach to housing or the management of Lake Tyers, and although he seems to have made genuine attempts at consultation, his attempts to advocate on behalf of Aboriginal people were ineffectual against the combined power of Davey, Holden and Howe.

By the end of 1964, the Board and the government were forced to recognise that the housing program was not having the desired assimilatory effect that they had anticipated. Lake Tyers remained operational and served as a symbolic rallying point for Aboriginal resistance to assimilation. Families who had left to take up new houses applied to return to the reserve, although these applications were routinely denied by the Board. ${ }^{36}$ The campaigning of Aboriginal leaders and groups such as the Aborigines Advancement League and the Council for Aboriginal Rights to secure Lake Tyers as a permanent reserve was gaining momentum and support, adding to pressure on the government. ${ }^{37}$

As the Board's housing subcommittee, Holden, Howe and Davey developed a new strategy: the transit village scheme was designed to move all of the remaining residents from the reserve to a single, temporary, managed site, and to therefore expedite the closure of Lake Tyers. Felton had anticipated the announcement of the scheme and authored a report to the Board articulating his support for the retention of Lake Tyers in which he expressed his opposition to any proposal to rebuild the

32 NAA, B357, 166; NAA, B357, 67.

33 NAA, B357, 166.

34 Felton, 'Philip Felton', 57.

35 NAA, B357, 67.

36 Stan Davey, 'Press Release by Aborigines Advancement League', 9 December 1964, CAR Papers, SLV, MS12913, Box 3/8; NAA, B314, 11; Broome, Fighting Hard, 105.

37 See Broome, Fighting Hard; Taffe, 'Fighting for Lake Tyers', 157-71. 
Settlement on any other site'. He warned that such a scheme would 'disintegrate and disorganise the people'. ${ }^{38}$ Felton's protest had no impact on the Board's direction, because the ultimate aim of the assimilation policy as it was being implemented in Victoria by the Board was to physically separate Aboriginal people and families from one another, to disconnect them from the land at Lake Tyers and to disrupt Aboriginal social and political organisation.

\section{Planning for the Morwell transit village}

The Board began to scout for possible sites for the transit village at the beginning of 1965, concentrating on the Latrobe Valley. Within a few months they were offered 4 acres of land on the outskirts of Morwell (see Figure 1) by the Australian Paper Mills (APM).$^{39}$ The lease was free, short and well suited to the Board's plans. The Board's housing subcommittee began to further develop their plans, based on the foundational idea that the village would provide short-term accommodation and training for families living at Lake Tyers before moving them into standard housing elsewhere..$^{40}$ The township of Morwell was a convenient location for the Board. Holden's connections with the Apex Club, his prominence as a local businessman, the free short-term lease offered by the APM, and the presence of a branch of the architecture firm contracted to the Board, meant the Board had an established network in the town that would have increased its attraction to the Board. ${ }^{41}$ Networks such as these have been identified in the development of Aboriginal housing in the assimilation era, raising questions about the motivations of administrators working for bodies such as the Board in their selection of sites for development. ${ }^{42}$ The networks and connections the Board had in Morwell may have informed the confidence expressed by Holden and Davey following their application to the Morwell Shire Council for the site of the transit village to be rezoned as residential land. Following their submission to the Shire Council, the 2 men were so sure the application would be approved they commenced discussions with engineers to begin work on the site. ${ }^{43}$

\footnotetext{
38 NAA, B356, 44.

39 NAA, B357, 77.

40 NAA, B357, 77.

41 NAA, B357, 77.

42 Woolmington, 'The "Assimilation"', 25-37; Ellinghaus and Healy, 'Micromobility', 46.

43 NAA, B314, 11.
} 


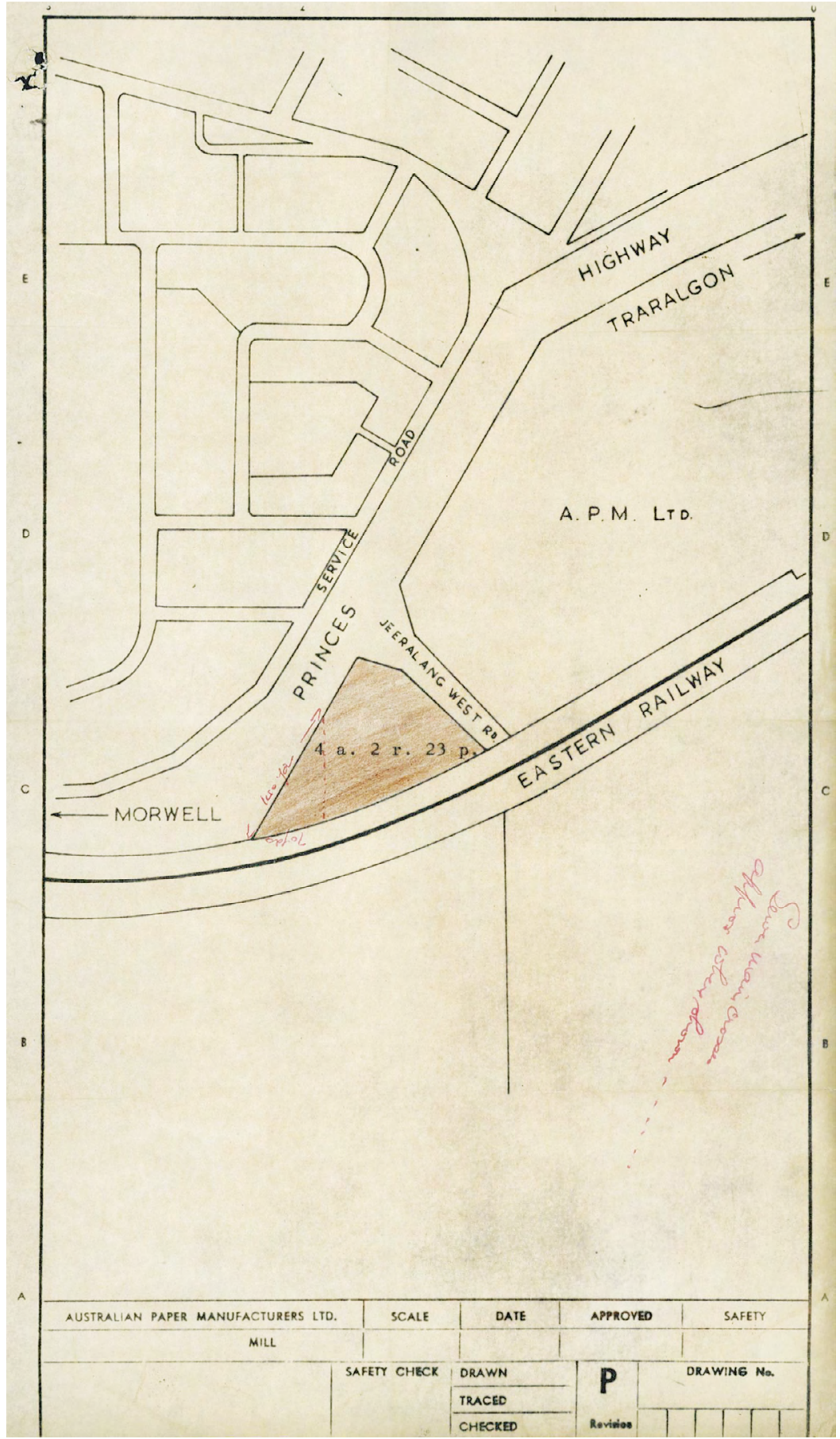

Figure 1: Map showing the proposed site of the Morwell transit village, on the eastern outskirts of the town.

Source: NAA, B357, 77. Reproduced with permission of Australian Paper Mills. 
It was Holden who authored most of the plans for the transit village. His notes reveal the emphasis on the temporary and transitional aspect of the settlement: it was a 'transit training settlement', 'a staging settlement', and future residents should 'view it as a period for finding their feet'. Holden stressed that the village was not to be a 'permanent home', nor was it a place that Aboriginal people would be permitted to return to once they had left, in contrast to the role of Lake Tyers. The spatial qualities of the transit village were important to the committee. They suggested that 6, 3-bedroom prefabricated houses for families were required, a further 6 for couples, and a motel centre for single people, who the Board expected would mostly be men. It was decided that 'the Board would landscape the area as part of the original concept', and 'start the front gardens', and encourage residents to establish 'their own garden plots'. These plans reveal the expectation of some members of the Board that there was potential for the space to influence how the residents spent their time, and the assumption that residents - although temporary - should invest time and effort in the socially acceptable activity of developing gardens. ${ }^{44}$

The design also reveals the Board's views about how the white community of Morwell could relate to the transit village. The physical location of the transit village was such that the movement of Aboriginal people into the township of Morwell would have been difficult. However, selected white visitors to the site were to be encouraged. Holden, perhaps conscious of his position on the Board and also in the community of Morwell, argued that particular attention should be paid to the 'Community Activities Building', which, he suggested, could be 'something of a showpiece' where local community organisations such as Apex and the CWA could be involved in activities. ${ }^{45}$ Other aspects of the appearance of the transit village were also important to the Board: they decided the roof tiles of the houses should be of 'varying colours', and that efforts should be made to make the village 'as attractive as possible, not only for the residents but also for the outside public'. ${ }^{46}$ The transit village was to be a showcase of assimilation at work and visible evidence of the Board's investment in Aboriginal housing.

Yet the Board claimed that the 'whole emphasis' of the scheme was on 'training' ${ }^{47}$ Rather than consulting with Aboriginal people about the kinds of education and training they might find useful, the Board contacted the Director of Adult Education, Colin Badger, who suggested the village be used to provide training for residents to become 'members of the general community'. Badger suggested that although male residents of the village should be 'encouraged to make articles they should not be taught or encouraged to manufacture Aboriginal curios', and that

44 NAA, B357, 77.

45 NAA, B357, 77.

46 NAA, B314, 11.

47 Victoria, Aborigines Welfare Board, Annual Report, 1965. 
'the less reference there was to Aboriginal matters the better'. ${ }^{48}$ The history of the production of items such as baskets and boomerangs to generate income and as a way of 'keeping culture' has been well established. ${ }^{49}$ At Lake Tyers in particular, as Sylvia Klein has shown, the production of such items served multiple purposes. ${ }^{50}$ Their sale to the public generated an income that provided a way of 'circumventing both the ration economy of the reserve and the racial inequalities of the outside world', and the production of cultural items allowed Aboriginal people to 'undercut institutional impositions aimed at their integration into wider Australian society'. ${ }^{51}$ The decision of the Board to prohibit the use of the workshop at the Morwell transit village to produce potentially lucrative items such as boomerangs shows the Board's intent to ensure that Aboriginal people engaged with the economy in carefully managed ways that were conducive to the Board's assimilationist aims, and exposes the fallacy of the Board's assertion that the development of the transit village was, in part at least, intended to foster economic independence. Badger's suggestion that the male residents of the village should 'not be taught' to manufacture Aboriginal 'curios' exposes his ignorance of Aboriginal cultural strength in Victoria. A program of deculturation was at the core of the transit village scheme, and Badger's recommendations - that the Board fully accepted - were intended to deprive residents of their heritage just as they had been deprived of their right to stay at Lake Tyers.

Little attention was given to means for increasing employment prospects for residents at the village. The Board's unexamined expectation was that following an undetermined 'trial period' at the transit village, residents would move into a standard house and find work and maintain rental payment. Badger made no suggestions for how practical assistance could be provided to gain entry into the local labour market. Instead, the focus of the scheme was teaching Aboriginal people how to live in white housing and among white communities, with no support for development of skills to improve their employability in the industrial Latrobe Valley. The State Electricity Commission (SEC), the Australian Paper Mill and the Gas and Coal Commission were the 3 largest employers in the growing industrial hub of Morwell in the 1960s and were potential employers. A number of Aboriginal men already living in Morwell were employed by the SEC, and some worked for the Morwell Shire Council. ${ }^{52}$ Although the Board emphasised the limited employment opportunities as another key reason for people to leave Lake Tyers, they did not establish any connections with potential industry partners for vocational training in connection with the main industries in the Latrobe Valley. And as the employment market was dominated by heavy industrial work, there were

48 NAA, B314, 11.

49 See Broome, Fighting Hard, 18-22.

50 Kleinert, 'Aboriginal Enterprises', 172.

51 Kleinert, 'Keeping up the Culture', 92.

52 Legg, Heart of the Valley, 254-56. 
very limited job prospects for women in Morwell. ${ }^{53}$ Felton was more familiar with the difficulty that many Aboriginal people faced in securing work, and wrote to the Board's local welfare officer to ask if there was 'an expansion of employment in the unskilled category' in the Latrobe Valley. Felton was also concerned by the limited employment opportunities available to teenaged school-leavers from Lake Tyers. ${ }^{54}$

The transit village site was also ill-suited to younger children, as the location was dangerous, wedged between the busy Princes Highway and the railway line, and the distance from town meant that the children could not walk to school. The Board budgeted for the purchase of a vehicle specifically so that the village manager would be able to transport children to and from school. ${ }^{55}$ As members of the Advancement League pointed out, children living at the Lake Tyers could as easily be transported in this way to one of several schools in the district 'as thousands of other Victorian school children travel much longer distances to school'. ${ }^{56}$

The government expressed support for the Morwell transit village scheme and promoted the role of the new settlement as a favourable alternative to Lake Tyers reserve. The Morwell transit village became another argument used to support the government's commitment to close Lake Tyers. The Chief Secretary, Arthur Rylah, argued that the transit village was the 'answer' to the 'depressing and demoralising conditions' at Lake Tyers. ${ }^{57}$ The isolation of the reserve was cited frequently as a reason for its closure, measured as geographical distance from jobs, schools and training and unfavourably compared with the site of the proposed Morwell transit village. Yet although the transit village was closer to a town than Lake Tyers, it was also isolated: located on the outskirts of town, bordered by the highway and the railway line. In this way, the transit village was not unlike the camps at Mooroopna, Robinvale and Jackson's Track that the Victorian Government had been so swift to condemn and to dismantle following the passing of the Aborigines Act 1958. The transit village shared an isolated and segregated fringe location with the transitional housing settlements of Manatunga and Rumbalara. By 1965 these had both drawn negative publicity, condemned by many Aboriginal people and leaders for their poor design, the excessive surveillance and control of the managers. ${ }^{58}$

There was no consultation with Aboriginal people about any aspect of the Morwell transit village. The Board was aware of reports that Aboriginal people living in Gippsland 'were saying that they would not go to the Village'.59 Felton asked the local welfare officer, stationed in Morwell, to determine what Aboriginal people

53 Legg, Heart of the Valley, 256.

54 NAA, B357, 77.

55 See AWB Housing Sub-Committee minutes, NAA, B314, 11.

56 NAA, B356, 44.

57 Victorian Parliamentary Debates (hereafter VPD), 277, 2768.

58 VPD, 277, 2768.

59 NAA, B314, 11. 
'are really saying about the Transit Village proposal'. Their responses show that many Aboriginal people believed that the transit village was just another government institution designed to interfere in their lives. Charles Harrison asked: 'What's this about a new mission ... I wouldn't want to live there'. Rupert O'Rourke agreed, and said he was reluctant to live in the village because ' $[t]$ here will be a white manager in charge'. Others suggested that the transit village 'could be a success', but that it depended on the 'type of manager appointed' and that the 'people themselves' should 'have some say in the matter'. The general consensus of Aboriginal people was that 'Lake Tyers [was] being transferred to Morwell'. ${ }^{60}$ These comments demonstrate how Aboriginal people understood the Board's aims in developing the transit village: another space where their lives would be subject to the control and surveillance of a white manager carrying out the policies of the government, in the same vein as the missions and reserves of the past. They also recognised that the Morwell transit village scheme presented a threat to Lake Tyers. ${ }^{61}$

\section{'We will never leave no matter what happens': Holding on to Lake Tyers}

The campaign to save Lake Tyers reserve received wide publicity due to the political agitation and lobbying by Aboriginal leaders and groups who advocated for Aboriginal rights. Laurie Moffatt and Doug Nicholls, along with the Council for Aboriginal Rights and the Aborigines Advancement League, maintained a visible presence in the media as they challenged the government to improve the appalling conditions on the reserve, and to extend the provision of housing to families living in other areas of the state. ${ }^{62}$ Doug Nicholls was a highly visible and vocal advocate for the retention of Lake Tyers under Aboriginal control. He was working as a field officer for the Aborigines Advancement League in 1965 and travelled extensively around the state providing practical assistance such as gaining employment and securing legal advice. With Nicholls as spokesperson, the League lobbied hard to save Lake Tyers, and its members were particularly conscious that the importance of Lake Tyers to Aboriginal people in Victoria extended beyond the historical and cultural connections Aboriginal people had to the reserve. Nicholls expressed alarm that the 'promise of security' that the reserve held for Aboriginal Victorians could be broken, and that eventual rehousing elsewhere would cause 'unnecessary emotional upheaval'. ${ }^{63}$

60 NAA, 357, 77.

61 Richard Broome characterised the transit village as a 'dagger at the heart of Lake Tyers'. Broome, Aboriginal Victorians, 325.

62 Formed in 1957, the League comprised mostly white members and had some 28 branches throughout regional Victoria and Melbourne, see Broome, Fighting Hard.

63 Doug Nicholls, 'Statement on Aboriginal Affairs'. 
The League and Nicholls were equally strident in their opposition to the Morwell transit village. When the scheme was announced, Nicholls had responded that he welcomed the news that 'after 130 years of Aboriginal Welfare that the Government is prepared to provide adult education' in the Latrobe Valley, but he questioned why such training would be delivered in a 'new fringe settlement' when the money could instead be spent at Lake Tyers where 'the Aborigines desire to live'. ${ }^{64}$ The lack of consultation with Aboriginal people was also emphasised by Nicholls, and in July 1965, the Aboriginal Congress (the all-Aboriginal branch of the League) made public 2 resolutions in relation to the village: 'We want the Board to ask us whether or not we want these houses', and 'The Board should also ask the people if they want to move from Lake Tyers to Morwell'. ${ }^{65}$

The developing relationship, in this period, between Aboriginal people and proAboriginal rights groups such as the Aborigines Advancement League and the Council for Aboriginal Rights (the Council) has been well documented. ${ }^{66}$ Formed in 1951, the Council comprised a mostly white membership, and campaigned to increase public knowledge and understanding of Aboriginal issues. Although the Council did not have numerous branches like the League, many trade unions, organisations and other groups were affiliated to it, and this increased its capacity to influence government. ${ }^{67}$ Gene Mobourne, resident at Lake Tyers, capitalised on the interest of the Council. Mobourne recognised the Board's deliberate failure to intervene when problems arose between residents and the manager and suggested that some of the trouble on the reserve was being deliberately fostered to justify its closure. He shared this information with Pauline Pickford, secretary of the Council, telling her that the Board was 'using' people to cause trouble 'so that all the people will have to go, in other words it will leave no one here on Lake Tyers' ${ }^{68}$ His letters also illustrate the strength of the position of residents fighting against the Board's pressure to compel them to leave. He wrote: 'I've talked to everybody and told them not to leave Lake Tyers whatever the Welfare Board do or say even if they don't supply them with their rations', and that the residents considered the reserve their 'rightful home Lake Tyers'. Mobourne added that he expected the information he was providing to Pickford to 'make a good opening for the Council ... and other organisations to step in and give the Welfare Board what.o' ${ }^{69}$ Letters such as Mobourne's that provided important information to activist groups operating in Melbourne were essential to the campaign against the Board and the closure of the reserve.

64 Doug Nicholls, 'Statement on Aboriginal Affairs'.

65 'Plan for Aboriginal Settlement Condemned', Age, 12 July 1965, 9.

66 See Taffe, 'Fighting for Lake Tyers'; Broome, Fighting Hard.

67 Harris, 'A "New Deal”, 132-34.

68 Gene Mobourne, 16 February 1965, CAR Papers, SLV, MS12913, Box 7/4.

69 Mobourne, 16 February 1965. 
Laurie Moffatt was also active in opposing the closure of Lake Tyers and the development of the transit village. Moffatt, who was born at Ramahyuck and married at Lake Tyers, had long been a fierce advocate for the retention of Aboriginal land. He told The Argus in 1952 that: 'We do not want to see Lake Tyers finally sold to the white man in the same way as Ramahyuck, Condah, Ebenezer Mission, and Corranderrk reserves have been sold. ${ }^{70} \mathrm{~A}$ decade later when residents of the reserve petitioned the government for permission to travel to Melbourne so that they could protest against its closure, Moffatt was the first to sign. ${ }^{71} \mathrm{He}$ utilised his well-established connections with Aboriginal rights groups and explained to Pauline Pickford the problems at Lake Tyers: no public telephone, no water connected to the houses, insufficient beds, regulations that residents required permission to leave for 'even a few hours', and the lack of 'ownership of their homes'. He concluded with the following demand: 'It is time the Aboriginal people as a group be given assistance and the possibility of running their own affairs. ${ }^{72}$

Moffatt's grassroots activism was key to stopping the transit village. He had conversations with Aboriginal people living in Morwell and addressed approximately 40 residents at a meeting at the end of August 1965, during which shared disapproval of the transit village scheme was aired. ${ }^{73}$ Moffatt was not averse to forming relationships with those whose motivations differed from his own. He worked with groups that he believed could facilitate challenges to government policy and further the aims of Aboriginal Victorians. In 1965 he attended a Morwell Shire Council meeting alongside members of the Morwell Protest Committee, a group composed of 8 residents who lived opposite the proposed transit village site. ${ }^{74}$ Harvey Stritch, secretary of this committee, informed the Morwell Shire Council that the group's 'primary objection' to the transit village was due to concern for 'the welfare of these people', claiming that they had 'nothing against the Aborigines being integrated into the community' but that it felt 'the proposed settlement [was] merely isolation and not integration'. Stritch suggested that integration could be achieved by selecting 4 Aboriginal families to be 'scattered throughout the community' and made similar statements to the local newspapers. ${ }^{75}$ Stritch's use of the term 'integration' and his assertion that this was better than assimilation are demonstrative of the shifting understandings of what assimilation was during this period. The Morwell Shire Council understood assimilation differently: they had initially rejected the possibility of a 'mass settlement' in Morwell but expressed agreement with the 'assimilation of

\footnotetext{
70 Argus, 28 January 1952, 4.

71 Joanne Bach, 'Moffatt, Lawrence Francis (Laurie) (1897-1966)', Australian Dictionary of Biography, National Centre of Biography, The Australian National University, adb.anu.edu.au/biography/moffatt-lawrence-francislaurie-13105/text23709, published first in hardcopy 2005, accessed online 1 June 2019.

72 Laurie Moffatt as dictated to Pauline Pickford, September 1961, CAR Papers, SLV, MS12913, Box 7/3.

73 Pauline Pickford, 'Press Statement to the "Age”', 16 September 1965, CAR Papers, SLV, MS12913, Box 5/7.

74 “'Give Us Back Our Land”; Plea Made', Morwell Advertiser, 6 September 1965, 2.

75 Morwell Shire Council Minutes 1965, Public Record Office Victoria, VPRS 2867, Unit 14; Morwell Advertiser, 24 June 1965, 1, 2.
} 
two or three families' ${ }^{76}$ Moffatt was likely aware of the racial prejudices of Stitch and the group he represented. But he shared the same aim as Stritch and the Morwell Protest Committee, and in spite of the different reasons behind their protests, he effectively utilised Stritch's objections to contribute to the eventual defeat of the transit village scheme.

With the exception of items featuring Nicholls and Moffatt, media coverage of Aboriginal opinion on the scheme was limited. Yet the publicised comments made by these 2 leaders were especially powerful in that they focused on land. Moffatt argued that the money the Board proposed to spend on the transit village at Morwell should be spent on Lake Tyers. ${ }^{77}$ 'Why can't the Government spend the money on our own settlement at Lake Tyers', he asked at a meeting of the Gippsland Trades and Labour Council, adding: 'We should have the home of our choice instead of being brought to Morwell. We are only asking for a little bit of Australia to be given back to us. ${ }^{78}$ The Victorian Government, and the Board, led by Holden, Howe and Davey, already knew that this was what Aboriginal people wanted. Lake Tyers served as a symbolic point of resistance to the assimilation policy and fostered political awareness and activism among Aboriginal people and their supporters. It was because Lake Tyers was proving such an impediment to the assimilation of Aboriginal Victorians that the government and the Board were so determined to close it down.

\section{The Morwell transit village in parliament}

As the fight against the Morwell transit village played out in Gippsland, the future of Lake Tyers remained uncertain. A new Bill introduced by the government in March 1965 sought to further entrench the policy of assimilation and guarantee the closure of Lake Tyers. The Bill also sought to move administration of the Board away from party politics by shifting its administration to the Minister of Housing. This legislation was fiercely contested by Aboriginal leaders and their supporters. Doug Nicholls called for the government to 'transfer to the Aboriginal people communal ownership of Lake Tyers Reserve'. ${ }^{79}$ He organised a march on parliament, along with Laurie Moffatt, and sought the support of the leader of the opposition. Nicholls was well-respected, politically active and articulate: he embodied everything that the government did not want Aboriginal people to be. The government's reaction to Aboriginal political activism is evident in the parliamentary debates. The chairman of the Aborigines Welfare Board, the Minister of Transport Ralph Meagher, suggested that all the 'fuss and propaganda, the marches through Melbourne and the other

76 'Council Object to Mass Aborigines Settlement', Morwell Advertiser, 10 May 1965, 1.

77 'Aboriginal Plan Called "Unfair", Morwell Advertiser, 6 September 1965, 2.

78 'Aboriginal Plan Called "Unfair", Morwell Advertiser, 6 September 1965, 2.

79 Nicholls, 'Statement on Aboriginal Affairs'. 
claptrap' was designed by the League to defend the residents of Lake Tyers who 'refused' to accept the responsibilities of assimilation and instead wanted to 'stay at Lake Tyers and be fed for sitting down and doing nothing'. Meagher claimed that parliament was inundated by complaints from the Advancement League; another minister accused Nicholls of 'cheap headline-hunting', suggesting that Aboriginal people were 'simple souls' who could be 'used by anyone' such as the Labor party. ${ }^{80}$ Such comments are evidence of the effectiveness of Nicholls's campaigning, and the broader groundswell of political and grassroots resistance against government policy.

Through the debating of the Bill, the government continued to question the importance of Lake Tyers to Aboriginal people. The government dismissed any suggestion of the retention of the reserve as an open village as advocated by Moffatt, Nicholls and their supporters, stating that should such a scheme be allowed the result would be 'a large scale settlement of people who were not part of this society of ours but were, in fact, an alien race within it'. ${ }^{81}$ The location of the reserve, 'at the end of a bush track, 20 miles from the nearest town, with no employment, no prospects for the future, and segregated, apart and alone', was framed as problematic. ${ }^{82}$ But this was one of the qualities of the reserve that many Aboriginal people from Gippsland valued. Lake Tyers was a space of refuge not complicated by the need to negotiate spaces that could be discriminatory or hostile. Even as the government condemned the notion of a separate space for Aboriginal people, they promoted the idea of the Morwell transit village as 'a special place' and a 'haven' for Aboriginal people, perhaps in an attempt to appropriate language used by Aboriginal people to describe Lake Tyers. ${ }^{83}$

The determination and the motivations of government to close Lake Tyers was laid bare in the heated parliamentary debates over the new Bill. The continued presence of Aboriginal people committed to living together as a community on land that held deep significance to them provided an uncomfortable reminder to the government of the position of Aboriginal people as owners of the land. Arthur Rylah aimed to undermine this when he suggested that activist groups had persuaded 'Aboriginal people that they are different, that they are special people ... that the white man has stolen their land, and that they should demand that the white man turns it back to them'. ${ }^{84}$ Meagher declared that he would have nothing to do 'with any proposition which seeks to set up in this community two races', and asserted that he hoped 'all people of Aboriginal descent will stop this silly looking back to a past which is irretrievably lost' ${ }^{85}$ This, despite all the explanations and justifications made by the

80 VPD, 278, 3691, 3704. In 1964 Harold Blair had unsuccessfully stood for parliament against Meagher, an act described by the deputy premier Arthur Rylah as using 'candidature as a vehicle for personal attack'; VPD, 277, 2772.

81 VPD, 278, 3689.

$82 V P D, 278,3689$

$83 V P D, 278,3689$.

$84 V P D, 278,3689$.

85 VPD, 278, 3693. 
government suggesting otherwise, was the underlying motive driving the closure of Lake Tyers and indeed the policy of assimilation itself: the government was determined to make complete the dispossession of Aboriginal people. The repeated attacks on Lake Tyers and attempts to undermine Aboriginal people's articulation of their connection to the reserve show that the government understood very well the connection between Aboriginal identity and land and reveals the government's perspective of the need for assimilation.

The government's Bill passed. Davey was made Board chairman, with Holden as his deputy. ${ }^{86}$ Despite this, the Morwell transit village scheme was defeated when the application to rezone the 4 acres of the proposed transit village site from rural to residential was rejected by the Morwell Shire Council in September 1965. ${ }^{87}$ A television program, Watch This Space, was broadcast the following day and featured both Nicholls and Moffatt, providing them with the opportunity to comment on the failure of the scheme. They reiterated their opposition to the scheme and to the Board's ongoing disregard for consultation with Aboriginal people. Moffatt expressed frustration that Aboriginal people were 'being pushed around', while Nicholls reiterated his assertion that money approved for the transit village should instead be spent at Lake Tyers, where 'the people are more than happy'. ${ }^{88}$ The Council for Aboriginal Rights and the League expressed relief, and the League expressed hope that the failure of the scheme would lead the Board to 'consider a radically new approach to Lake Tyers' based on consultation with Aboriginal people. ${ }^{89}$ Felton suggested to the Board that assurances be given to residents of Lake Tyers, and that attention be refocused to improving conditions on the reserve. ${ }^{90}$ The opposition of Aboriginal people and their supporters towards the scheme, in the broader context of the contested nature of Aboriginal affairs, including the campaign to save Lake Tyers, had been successful.

Davey was infuriated, but his following attempts to push ahead with a settlement in Morwell proved futile. ${ }^{91}$ At the end of October 1965, just over a month after the Shire Council's decision, it was announced by the government that the transit village scheme would be abandoned, due to the prejudices of 'a minority of Morwell residents', and the Shire Council's refusal to rezone the land.${ }^{92}$ It did not acknowledge that the pressure applied by Aboriginal leaders and pro-Aboriginal groups had made public the strong resistance to the closure of Lake Tyers, and the understanding of Aboriginal people that the transit village scheme would be a precursor to this closure. Clearly, the effectiveness of Aboriginal political activism during this period

86 VPD, 278, 3689.

87 “"NO” to Site for Aborigines' Transit Area', Morwell Advertiser, 16 September 1965, 1.

88 NAA, B357, 77.

89 'Morwell Rejects Welfare Board Plan', Smoke Signals, 1965, 14; Pauline Pickford, 'Press Statement to the "Age"'.

90 NAA, B356, 44.

91 'Morwell Denies Prejudice over Aboriginal Village', Sun, 27 October 1965, 5.

92 'Aborigines' Home Issue Still Alive', Morwell Advertiser, 7 October 1965, 1, 7. 
was growing, as was the Board's awareness that efforts would be futile if they continued to make decisions that did not have the support of Aboriginal people and their allies. ${ }^{93}$

\section{Conclusion}

The defeat of the Morwell transit village scheme was pivotal to a shift away from the policy and practices of assimilation in Victoria. The space left by the transit village scheme was filled with plans for the development and continuation of Lake Tyers in accordance with Aboriginal aspirations. A new committee, comprising 3 Board representatives and 3 representatives from the Advancement League, began investigating the future possibilities of Lake Tyers reserve. An alternative proposal to a development was made, resulting in the opening of the Lionel Rose Centre in Morwell in 1969. ${ }^{94}$ Crucially, this centre operated parallel to Lake Tyers, rather than as an alternative to the reserve, a development in keeping with what Aboriginal people wanted: access to opportunities as well as the retention of Aboriginal land at Lake Tyers.

Towards the end of the 1960s, assimilation came to be rejected by governments all over Australia. The Aborigines Welfare Board was abolished in 1968 and replaced with a Ministry of Aboriginal Affairs. Under the Aboriginal Lands Act 1970 (Vic), the Victorian Government announced that Lake Tyers would be permanently reserved under the perpetual licence of an Aboriginal trust. ${ }^{95}$ This was the first Act of its kind in Australia, and it finally provided official, binding acknowledgement of Aboriginal people's connection to and ownership of Lake Tyers. The ongoing activism of Aboriginal people changed the way that government wrote policy, and the failure of the transit village scheme is testament to how the government's relentless pursuit of assimilation faced equally relentless resistance.

\section{Acknowledgements}

The author would like to thank the anonymous reviewers of this paper, as well as Max Kaiser, for their helpful feedback. The author would also like to thank the late Colin Tatz for his valuable suggestions on this work.

93 Harris, 'A “New Deal”', 166.

94 Victoria, Ministry of Aboriginal Affairs, Annual Report, 1970.

95 Aboriginal Lands Act 1970 (Vic). 


\section{References}

\section{Archival sources}

\section{National Archives of Australia (NAA)}

B314, 10, Minutes, 1962-1964. Aborigines Welfare Board.

B314, 11, Reference Copy of Minutes, 1965-1967. Aborigines Welfare Board.

B336, 1, Housing (Member) - Housing General. Aborigines Welfare Board.

B336, 3, Housing (Member) - Cases. Aborigines Welfare Board.

B336, 23, Aboriginal Housing in Victoria. Aborigines Welfare Board.

B336, 25, Housing (Member) - Bruthen. Aborigines Welfare Board.

B336, 26, Housing (Member) - Beaconsfield. Aborigines Welfare Board.

B336, 27, Housing (Member) - Nowa Nowa. Aborigines Welfare Board.

B336, 31, Housing (Member) - Bairnsdale - Lakes Entrance and district. Aborigines Welfare Board.

B356, 44, Policy, 1964-1965. Aborigines Welfare Board.

B357, 67, 1965 - Districts - Gippsland. Aborigines Welfare Board.

B357, 77, 1963-1965 - Districts - Gippsland - Proposed Morwell Village. Aborigines Welfare Board.

B357, 166, 1961-1964 - Social Worker's Reports - P J Boas; S M Goldsworthy; M C Taylor; A West; H McDonald; and; P E Felton. Aborigines Welfare Board.

B358, 4, Property Officer's Reports - Gippsland and Healesville, 1964-1967. Aborigines Welfare Board.

\section{Public Records Office Victoria}

Morwell Shire Council Minutes 1965, Public Record Office Victoria, VPRS 2867, Unit 14.

\section{State Library Victoria (SLV)}

Davey, Stan. 'Press Release by Aborigines Advancement League', 9 December 1964. Council for Aboriginal Rights Papers, SLV, MS12913, Box 3/8.

Mobourne, Gene. 16 February 1965. Council for Aboriginal Rights Papers, SLV, MS12913, Box 7/4.

Moffatt, Laurie, dictated to Pauline Pickford, September 1961. Council for Aboriginal Rights Papers, SLV, MS12913, Box 7/3. 
Nicholls, Doug. 'Statement on Aboriginal Affairs by Mr Rylah', 1 April 1965. Council for Aboriginal Rights Papers, SLV, MS12913, Box 3/7.

Pickford, Pauline. 'Press Statement to the "Age”', 16 September 1965. Council for Aboriginal Rights Papers, SLV, MS12913, Box 5/7.

\section{Government publications}

Aboriginal Land Act 1970 (Vic)

Aborigines Act 1957 (Vic)

McLean, Charles. 'Report Upon the Operation of the Aborigines Act 1928 and the Regulations and Orders Made Thereunder'. Victorian Parliamentary Papers, 1956-58, Vol. 2, Paper no. 18.

Victoria. Aborigines Welfare Board. Annual Report, 1962, 1965.

Victoria. Ministry of Aboriginal Affairs. Annual Report, 1970.

Victorian Parliamentary Debates, Forty-Third Parliament, First Session (1964-1965), Legislative Council and Legislative Assembly, Vol. 277, 2677-78, 2765-75.

Victorian Parliamentary Debates, Forty-Third Parliament, First Session (1964-1965), Legislative Council and Legislative Assembly, Vol. 278, 3654-710, 3854-58, 4072-90.

\section{Newspapers and journals}

Age (Melbourne)

Argus (Melbourne)

Morwell Advertiser

Smoke Signals (Melbourne)

Sun (Melbourne)

\section{Secondary sources}

Attwood, Bain. The Making of the Aborigines. Sydney: Allen \& Unwin, 1989.

Attwood, Bain. Rights for Aborigines. Crows Nest, NSW: Allen \& Unwin, 2003.

Broome, Richard. Aboriginal Victorians: A History since 1800. Sydney: Allen \& Unwin, 2008.

Broome, Richard. Fighting Hard: The Victorian Aborigines Advancement League. Canberra: Aboriginal Studies Press, 2015.

Chesterman, John and Brian Galligan, Citizens without Rights: Aborigines and Australian Citizenship. Melbourne: Cambridge University Press, 1997. doi.org/10.1017/CBO 9780511518249. 
Edmonds, Penny. 'The Intimate, Urbanising Frontier: Native Camps and Settler Colonialism's Violent Array of Spaces around Early Melbourne'. In Making Settler Colonial Space: Perspectives on Race, Place and Identity, edited by Tracey Banivanua Mar and Penelope Edmonds, 129-54. Basingstoke: Palgrave Macmillian, 2010. doi.org/10.1057/9780230 277946_9.

Ellinghaus, Katherine and Sianan Healy. 'Micromobility, Space, and Indigenous Housing Schemes in Australia after World War II'. Transfers 8, no. 2 (2018): 46-66. doi.org/ 10.3167/TRANS.2018.080204.

Felton, Philip. 'Philip Felton'. In Booroondara Connections: Stories of Aboriginal Connection by Residents of Booroondara, edited by David Crawford, 54-59, Balwyn North, Vic.: ANTaR Boroondara, 2008.

Fletcher, Meredith, Janice Chesters and Marlene Drysdale. 'Past, Present, Future: Reflection on Indigenous Rights via the Morwell "Village Haven". Journal of Australian Indigenous Issues 10, no. 3 (2007): 19-30.

Goodall, Heather. “Assimilation Beings in the Home”: The State and Aboriginal Women's Work as Mothers in New South Wales, 1900s to 1960s'. Labour History 69 (1995): 75-101. doi.org/10.2307/27516392.

Haebich, Anna. Broken Circles: Fragmenting Indigenous Families 1800-2000. Fremantle, WA: Fremantle Arts Centre Press, 2000.

Harris, Mark. 'A 'New Deal' for Victorian Aborigines, 1957-1968'. MA thesis, Monash University, Melbourne, 1998.

Jackomos, Alick and Derek Fowell. Living Aboriginal History of Victoria: Stories in the Oral Tradition. Cambridge: Cambridge Press Sydicate, 1999.

Jones, Jennifer. 'Aboriginal Education, Meritocratic Scholarships and the Country Women's Association of NSW 1962-1972'. In Conflict, Adaptation, Transformation: Richard Broome and the Practice of Aboriginal History, edited by Ben Silverstein, 122-39. Canberra: Aboriginal Studies Press, 2018.

Kleinert, Sylvia. 'Aboriginal Enterprises: Negotiating an Urban Aboriginality'. Aboriginal History 34 (2010): 171-96. doi.org/10.22459/AH.34.2011.07.

Kleinert, Sylvia. “'Keeping up the Culture”: Gunai Engagements with Tourism'. Oceania 82 (2012): 86-103. doi.org/10.1002/j.1834-4461.2012.tb00121.x.

Landon, Carolyn. Jackson's Track Revisited: History, Remembrance and Reconciliation. Clayton, Vic.: Monash University ePress, 2006.

Legg, Stephen M. Heart of the Valley: A History of the Morwell Municipality. Morwell, Vic.: City of Morwell, 1992.

Lydon, Jane. Fantastic Dreaming: The Archaelogy of an Aboriginal Mission. Lanham, MD: AltaMira Press, 2009. 
Manning, Corrine. "'If Aborigines Are to be Assimilated They Must Learn to Live in Houses": Victoria's Transitional Housing Policy'. In Contesting Assimilation, edited by Tim Rowse, 221-36. Perth: API Network, 2005.

Manning, Corrine. “'A Helping White Hand”: Assimilation, Welfare, and Victoria’s Transitional Housing Policy'. Labour History 87 (2004): 193-208. doi.org/10.2307/27516006.

Manning, Corrine. 'The McLean Report: Legitimising Victoria's New Assimilationism'. Aboriginal History 26 (2002): 159-76. doi.org/10.22459/AH.26.2011.07.

Rowse, Tim. 'Contesting Assimilation'. In Contesting Assimilation, edited by Tim Rowse, 1-24. Perth: API Network, 2005.

Taffe, Sue. 'Fighting for Lake Tyers'. In 'Indigenous Victorians: Repressed, Resourceful and Respected', edited by Lynette Russell, special issue. LaTrobe Journal 85 (2010): 157-71.

Woolmington, Jo. 'The "Assimilation" Years in a Country Town'. Aboriginal History 15, no. 1-2 (1991): 25-37. 
This text is taken from Aboriginal History, Volume 43, 2019, edited by Ingereth Macfarlane, published 2020 by ANU Press, The Australian National University, Canberra, Australia.

doi.org/10.22459/AH.43.2019.05 